\title{
Mobile Application Aimed at Older Adults to Increase Cognitive Capacity
}

\author{
Ricardo Leon-Ayala, Gerald Gómez-Cortez, Laberiano Andrade-Arenas \\ Facultad de Ciencias e Ingeniería \\ Universidad de Ciencias y Humanidades \\ Lima, Perú
}

\begin{abstract}
The research work focuses on people with dementia of the Alzheimer's type, since, among the types of dementia, this is the most common worldwide. In Peru, more than 200 thousand adults over 60 years of age suffer from this disease and many others who still do not know it or are in its initial stage. Therefore, it was decided to create a prototype of a mobile application with memory games, riddles, reminders and different types of physical activities to perform during the day. The scrum methodology was implemented to promote good practices for team and collaborative work, in terms of us phases from inception to launch of the product which is the mobile application. In addition, balsamiq was used as a prototype design tool. And so the objective of creating the prototype for its development was achieved. The goal of creating the prototype for the application was achieved. Positive results were obtained in terms of user and customer satisfaction. This will allow the benefit of adults for the improvement of cognitive ability, being able to perform their daily activities in the best way and socializing with family and friends.
\end{abstract}

Keywords-Alzheimer's; balsamiq; mobile; prototype; scrum

\section{INTRODUCTION}

Dementia prevents us from performing the activities of daily living properly, as it is a syndrome that affects memory, understanding and behavior. Worldwide, dementia has become a major public health problem. Risk factors for dementia vary from country to country. It is estimated that the number of new cases of dementia each year worldwide is close to 7.7 million, with one new case every four seconds. Each year, there are 3.6 million new cases (46\%) in Asia, 2.3 million (31\%) in Europe, 1.2 million (16\%) in the Americas and 500,000 (7\%) in Africa [1].

Epidemiologists around the world have conducted research on the prevalence of dementia, with predicted estimates coming from a variety of sources, including epidemiological surveys, hospital records and electronic medical record databases. A meta-analysis included 157 epidemiological studies conducted worldwide between 1980 and 2009. The report showed that the prevalence of dementia among people over 60 years of age was $5.8 \%$ to $8.0 \%$, showing an exponential increase with age, doubling every five years. A different global metaanalysis study reported similar results, with a prevalence rate of $4.8 \%$ for people over 60 and a period prevalence rate of $6.9 \%$.

Although dementia affects the world, it represents a unique danger for Latin American and Caribbean countries compared to the lower, stable and declining prevalence rates in Europe and the United States, the prevalence of dementia in people over 65 years of age in this region of the continent is high, and increasing, between $7.1 \%$ and $11.5 \%$. In addition, there are several related risk factors, including significant genetic heterogeneity and social determinants of health [2]. In Peru, according to the Ministry of Health (Minsa) indicated that in 2019 more than 200 thousand people over 60 years of age suffer from dementia. This report was presented by the psychiatrist Manuel Escalante.

Due to the COVID-19 pandemic, the government of Peru, through the former president Martín Alberto Vizcarra Cornejo, has been taking preventive measures since the first wave of this disease, such as the use of masks, face shields, social distancing, etc. One of these provisional measures was social isolation, a strict but necessary posture. In this situation, there was a statistically significant increase in the population in the levels of agitation, depression, appetite, eating disorders, nocturnal behavioral disturbances and aberrant motor activities [1]. It is not yet known what cognitive damage these measures may have caused in the population, according to experts the results of these new routines may be chaotic.

Among the types of dementia, Alzheimer's disease (AD) is the most common, accounting for $60-70 \%$ of dementia cases. In the initial stage of $\mathrm{AD}$, cognitive impairment progresses progressively, showing orientation difficulties, language alterations and cognitive dysfunctions. During the course of the disease many psychological symptoms occur in behavior, affecting activities of daily living [3].

According to the author [4], there is an inverse relationship between sedentary time and cognitive ability, although studies on this topic are inconsistent. However, not all sedentary challenges are equal. Passive sedentary behaviors, such as watching television, appear to be harmful; whereas more cognitively stimulating activities, such as reading, using a computer or solving puzzles, are shown to be associated with improved cognitive ability and recognition.

By means of the analysis carried out research work is to develop a mobile application model using basic principles of mental health experts. Enabling the improvement of FE and delaying future Alzheimer's problems in older adults.

The article is made up of sections. In Section II for literature review, in Section III, the methodology was applied to, In Section IV a case study was conducted, in Section V result and discussion, and finally in Section VI the conclusion and future work. 


\section{LITERATURE REVIEW}

The research topic of this article is cognitive ability in older adults, likewise, of the various applications created on the basis of cognitive enhancement, based on this I design an application to enhance the cognitive capacity of older adults through interactive games.

The author [5], reviewed the studies of the last decade in the field of cognitive training using communication and information technologies, also recorded those cognitive improvement strategies and thus evaluated the effectiveness of these programs, that is why I come to the following conclusion, entertainment applications, video games among others could be used in intervention studies for cognitive improvement of healthy or cognitively impaired individuals.

On the other hand, the author [6], It is recognized that there is limited understanding of how older adults use smartphones and how their use changes compared to younger users, in addition, mentions that based on data collected from the telephones of 84 healthy adults during the last three months, the most common characteristic is that they open fewer applications, take longer to perform daily tasks and send fewer text messages, then a cognitive analysis was performed on each respondent and it turns out that $79 \%$ had cognitive impairment, This is why their study suggests that researchers and developers should take cognitive impairment into account when developing any type of project.

On the other hand, according to the author [7], tells us that taking into account the illnesses of people due to their age, an application consisting of four modules was developed: news, reasoning games, reasoning questions and a calendar. The app was put to the test and the results show that there is an increased interest in memory games and entertaining brain games.

According to the author [8], modern cell phones have generated new interactive scenarios that require complex interfaces. The major operating system developers of these devices provide APIs for developers to implement their own apps, including different solutions for graphical interfaces, sensor control and voice interaction. While these resources are useful, there is no clear strategy to combine the multimodal interface with the possibilities offered by the device to identify and adapt to user needs, which is particularly important in areas such as environmentally assisted living.

In addition, the author [9], argues that digital apps for seniors should be evaluated to support senior independence and home care. Apps provide increasing opportunities for older adults and their family caregivers to educate, participate and share health information through digital platforms. Few applications have recorded evidence of availability for the elderly and their caregivers. By conducting a survey, the author concluded that technology use among older adults and caregivers was high. Usability and engagement of the mobile application was average. Additional training is needed for older adults and their caregivers, including that on specific behaviors for digital maintenance.

In conclusion, the good contributions of the authors mentioned for the development of this topic were analyzed, also, certain shortcomings were observed in the interactivity with the application, so a new contribution will be added by applying what was analyzed and incorporating new knowledge.

\section{Methodology}

In order to carry out the research, the agile Scrum methodology was used, is considered agile because it uses incremental and iterative process approaches. On the other hand, has proven to be more useful than the traditional waterfall model because it improves the productivity of the processes and helps to reduce the time consumed for their realization. In a traditional waterfall model, planning is performed prior to testing, in addition, the process is managed in phases and once it has been completed, it is not possible to return to the previous phase. On the other hand, Scrum at any stage changes can be made to improve the outcome. In Fig. 1, the Scrum flow is shown [10].

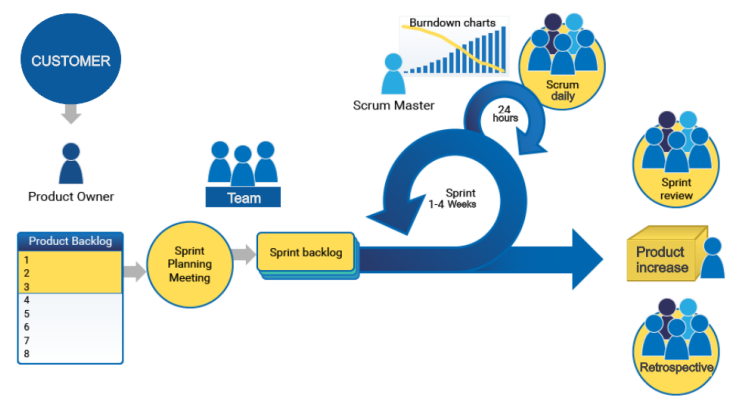

Fig. 1. Scrum Flow.

\section{A. Scrum}

The use of scrum involves integrating roles between work teams, an advantage of using scrum is that it allows teams to adapt quickly to manage and plan their work, since, each step of scrum allows you to plan, design, develop and test the code, all these activities are divided between roles [10], Fig. 2 shows the roles proposed by Scrum [11].

Scrum has three roles: Product Owner, Scrum Master and the Team:

1) The Product Owner: For this role, the manager is responsible for the definition and prioritization of the client's needs, in addition to communicating all the information of the client's requirements to the entire team and in this way maximize the value of the product.

2) The Scrum Master: Who assumes the role is the "Servant Leader" of the team, also known as moderator, is responsible for solving problems of the team, also motivates the same to develop its activities.

3) The Team: For this role, the person in charge is the entire team in charge of the development of the project, usually made up of 3 or 9 members. It is responsible for making the deliverables established in the Product Backlog, on the other hand, a characteristic of the team is its proactivity, ability to multitask and have the necessary knowledge to help in the activities of its colleagues [12]. 


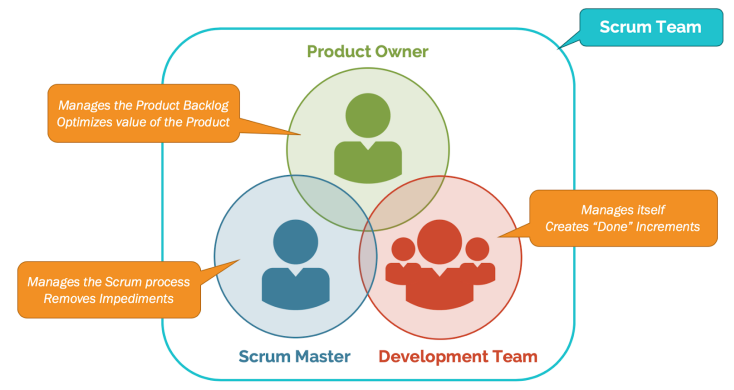

Fig. 2. Roles in Scrum.

\section{B. Scrum Practices}

Scrum has practices also called Scrum formalities: Daily Meeting, Sprint Review, Sprint Planning and Sprint Retrospective Meetings:

1) Daily Meeting: The meeting is held every day, the team discusses the problems and the process of the project.

2) Sprint Review: A meeting is held in which the team presents the results at the end of each Sprint to the owner.

3) Sprint Planning Meetings: A meeting is held to define the activities to be carried out during a Sprint.

4) Sprint Retrospective: The entire Scrum team meets with the objective of evaluating the team's performance during the Sprint and the practices to be carried out to improve team productivity [12].

\section{Structure of Scrum Development}

1) Requirements Stage: It is established to obtain the project planning requirements.

2) Definition of User Stories: It is the description of the functionality of the system, for which the requirements are analyzed in collaboration between the client and the team, the user stories will be improved throughout the life of the project.

3) User Stories Prioritization: The priority of each of the user stories is established and the order in which they will be developed is determined, taking into account which one is the most fundamental for the project and thus following a hierarchy [13].

4) Analogous Estimation: When the user stories are obtained, they go through an examination where the use of a tool or estimation method is required, this consists of a study of each of the user stories concerning the time that the scrum team believes it can develop it, this phase involves both time and the resources and expenses that may be required.

5) Definition of Sprint Speed: The speed and time of development of each Sprint is performed through an analysis that varies according to the experience of the Scrum team [14].

6) Creation of the Product Backlog: User stories, priorities and required tasks are included in a Product Backlog. t includes the features or short term requirements and long term functionalities that have been defined jointly by the development team and Product Owner, moreover, the points or level of effort for each task are established. During the Sprint process, assigned tasks are movable depending on the Product Owner's requirements [15].

7) Sprint Presentation: The Sprint is presented according to the requirements and the determined times, in this phase, the scrum team performs tests on what is presented and it is either accepted or rejected, this is repeated according to the number of sprints a project contains [16].

8) Feedback: At the end of the project or each sprint, the scrum team holds a feedback meeting where they analyze everything developed in order to know their successes and failures in all aspects, para poder mejorar en un próximo proyecto o Sprint.

\section{Development Tools}

1) Kotlin Programming Language: Kotlin is a programming language with $100 \%$ interoperability with Java that combines functionality and object oriented features so that developers can use it. Write a new file in an existing Java project or write a new file Use Kotlin applications from scratch. In addition, the official IDE is used for android development [17].

2) Android Studio: The Android operating system is a linux-based open source software, this means that it can be used by anyone for free and free of charge. It was developed primarily for portable devices, including tablets and smartphones. Its architecture allows compatibility with the Java language. Ever since the first version of Android 1.0 was released in 2008, have been developing it up to version 11. Android studio is being powered by IntelliJ IDEA, what is integrated development Environment (IDE) [18]. IntelliJ IDEA's contribution makes it even simpler to create Android applications.

3) FireBase: Firebase is a web application platform. Helping developers create quality applications. The data are stored as objects using the JSON format. Firebase does not depend on the most common queries, how to add, insert, delete or update. This tool is basically a backend for your system, used to store data used to store the data and use it according to your needs [19].

4) Balsamiq: It is software used to create diagrams of a web page, which is widely used by application designers [20]. Balsamiq encourages us to focus on the structure and content of a website, avoiding position and detail errors, at the same time it allows us to create prototypes quickly, recreating the experience of a computer board [21].

\section{CASE Study}

\section{A. Start-up Stage}

1) Requirements Identification: Table II lists the functional requirements of the system., based on the survey and results shown in Table I.

2) User Stories: Table II shows the list of User Stories created based on the functional requirements shown in Table II. 
TABLE I. REQUIREMENTS LIST

\begin{tabular}{|c|l|}
\hline $\mathrm{N}^{\circ}$ & \multicolumn{1}{c|}{ Requirements } \\
\hline $\mathrm{R}-1$ & $\begin{array}{l}\text { The application must have a section that allows me to register or } \\
\text { log in with an alternative account, Gmail, Facebook, etc. }\end{array}$ \\
\hline $\mathrm{R}-2$ & $\begin{array}{l}\text { The application should perform a test where I evaluate the phase in which } \\
\text { I am in encounter, early stage, middle stage or final stage. }\end{array}$ \\
\hline $\mathrm{R}-3$ & $\begin{array}{l}\text { The application allows me to select the preferred activities } \\
\text { depending on the phase I'm in. }\end{array}$ \\
\hline R-4 & $\begin{array}{l}\text { The application must show my progress during its use, in order to be able to } \\
\text { evaluate my improvement during the use of the application. }\end{array}$ \\
\hline R-5 & $\begin{array}{l}\text { The application should show me recommendations, advice or } \\
\text { information based on my results or the phase I am in. }\end{array}$ \\
\hline R-6 & $\begin{array}{l}\text { The application must have activities that include logic and } \\
\text { mathematics. }\end{array}$ \\
\hline R-7 & $\begin{array}{l}\text { The application should have a game customization stage } \\
\text { to improve my user experience. }\end{array}$ \\
\hline R-8 & $\begin{array}{l}\text { The application must show my results at the end of each section or } \\
\text { activity. }\end{array}$ \\
\hline
\end{tabular}

TABLE II. USER STORIES

\begin{tabular}{|l|l|}
\hline $\mathrm{N}^{\circ}$ & \multicolumn{1}{c|}{ User Stories } \\
\hline $\mathrm{H} 1$ & $\begin{array}{l}\text { As a user, I want the application to allow me to login } \\
\text { or register to have access to all functionalities.. }\end{array}$ \\
\hline $\mathrm{H} 2$ & $\begin{array}{l}\text { As a user, I want the application to have a test or } \\
\text { entry game to know what stage I am in. }\end{array}$ \\
\hline H3 & $\begin{array}{l}\text { As a user, I would like to have different sections where } \\
\text { I can evaluate my knowledge according to the stage I am in to perform } \\
\text { the activities your preferences. }\end{array}$ \\
\hline H4 & $\begin{array}{l}\text { I as a user, I want the application to show my progress as } \\
\text { I use the application to see my progress over time. }\end{array}$ \\
\hline H5 & $\begin{array}{l}\text { As a user, I want the application to suggest activities, information and } \\
\text { recommendations based on my results to improve my current state. }\end{array}$ \\
\hline H6 & $\begin{array}{l}\text { I, as a user, want the application to include mental reasoning } \\
\text { games to improve my cognitive memory. }\end{array}$ \\
\hline H7 & $\begin{array}{l}\text { I as a user, I want the application to allow me to customize } \\
\text { the games to enhance my user experience. }\end{array}$ \\
\hline H8 & $\begin{array}{l}\text { As a user, I want the application to show me the results at the } \\
\text { end of each section to observe my performance in each activity. }\end{array}$ \\
\hline
\end{tabular}

\section{B. Planning Phase}

1) Analog Estimation: At this stage, the complexity estimate is made with respect to the development of each story, for this purpose, the rating range is from 1 to 13,1 is the lowest level of complexity and 13 is the highest. he estimation is based on H1, since this is where the "Login" is developed, then by way of example, H5 is located in column 5, which indicates that $\mathrm{H} 5$ is 5 times more complex to develop than $\mathrm{H} 1$, the same logic applies to the other stories. Thanks to the analog estimation, an idea of the functional development of each story for a future project was presented. To arrive at the following result, the work team held a discussion on the estimation of each story, were also classified according to personal criteria. As shown in Table III.

TABLE III. ANALOG ESTIMATION

\begin{tabular}{|l|l|l|l|l|l|l|}
\hline & 1 & 2 & 3 & 5 & 8 & 13 \\
\hline H1 & 1-Login & & & & & \\
\hline H2 & & & & & & 13-Login \\
\hline H3 & & & & & & 13-Login \\
\hline H4 & & 2-Login & & & & \\
\hline H5 & & & & 5-Login & & \\
\hline H6 & & & & & 8-Login & \\
\hline H7 & & & & 5-Login & & \\
\hline H8 & & & 3-Login & & & \\
\hline
\end{tabular}

2) User Stories Prioritization: In order to arrive at the following result, the work team performed an analysis of each story to determine those that are most relevant to the operation of the mobile application, that is, is sorted according to priority, as shown in Table IV in the first column all the user stories are ordered, then the second column contains the information obtained in Table III, and each estimate is added according to the corresponding history and finally, in the last column, the prioritization is carried out, for this it is considered that user stories are important to develop first for the correct functioning of the application.

TABLE IV. User StORIES PRIORITIZATION

\begin{tabular}{|c|c|}
\hline \multicolumn{2}{|c|}{ User Stories } \\
\hline H-U & Priority \\
\hline H1 & 1 \\
\hline H2 & 2 \\
\hline H3 & 3 \\
\hline H4 & 4 \\
\hline H5 & 5 \\
\hline H6 & 6 \\
\hline H7 & 7 \\
\hline H8 & 8 \\
\hline
\end{tabular}

3) Definition of Sprint Speed and History Points: In order to carry out the following chart it was decided together with the development team to divide the Sprint into three deliverables, also details which user stories belong to each Sprint, for example, $\mathrm{H} 1$ and $\mathrm{H} 2$ belong to Sprint 1 . As shown in Fig. 3 , Sprint 1 has 14 points, this result was obtained thanks to the information in Table IV, the effort points obtained by the stories were added up there, $\mathrm{H} 1$ only obtained 1 point and $\mathrm{H} 2$ 13 points, Adding both values together gives the result. The sprint speed refers to the estimated time for the completion of a sprint, speed is determined by the development team, the equipment is new, is why at the beginning the speed is high, however, Sprint 3 the speed slows down as the team is already more consolidated.

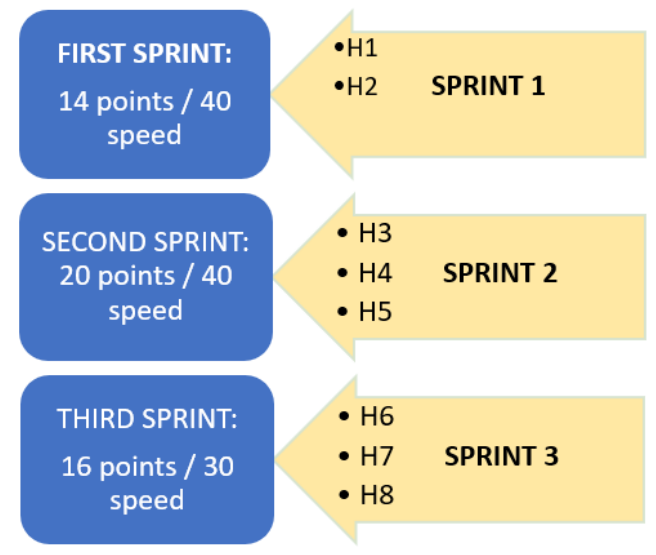

Fig. 3. History and Speed Points.

The Sprint Backlog table shows the three Sprint with their respective functionality to be developed, also, the estimated time for its development is defined. Estimated project development time is 3 months and 2 weeks. also, deliverables are completed in a shorter time. All this is shown in Table V:

4) Creation of the Product Backlog: For the creation of the complete backlog, ordered according to their history and priority, likewise, in the "Sprint" column, each story is sorted 
TABLE V. SPRINT BACKLOG

\begin{tabular}{|l|l|}
\hline Interface & Duration \\
\hline $\begin{array}{l}\text { Cognitive memory enhance- } \\
\text { ment application }\end{array}$ & $\begin{array}{l}3 \text { months } \\
\text { and 2 weeks }\end{array}$ \\
\hline Sprint 1: Login Interface & 1 week \\
\hline Sprint1: Registration Interface & 1 week \\
\hline Sprint 1: Home Interface & 2 week \\
\hline Sprint 1: Input evaluation & 2 weeks \\
\hline Sprint 2: Creation of activities & 2 weeks \\
\hline $\begin{array}{l}\text { sprint 2: Creation of interac- } \\
\text { tive games }\end{array}$ & 2 weeks \\
\hline $\begin{array}{l}\text { Sprint 3: Activity customiza- } \\
\text { tion functionalities }\end{array}$ & 2 weeks \\
\hline Sprint 3: Results reports & 2 weeks \\
\hline
\end{tabular}

according to which Sprint it belongs to, is why it has been numbered from 1 to 4 . Finally, the Estimate is listed from 1 to 13 , and this information is obtained from the analog estimating Table. The Product Backlog is shown in Table VI.

TABLE VI. PRODUCT BACKLOG

\begin{tabular}{|l|l|l|l|}
\hline User Stories & Priority & Sprint & Estimation \\
\hline $\begin{array}{l}\text { H1: As a user, I want the application } \\
\text { to allow me to login or register to have } \\
\text { access to all functionalities. }\end{array}$ & 1 & 1 & 1 \\
\hline $\begin{array}{l}\text { H2: As a user, I want the application to } \\
\text { have a test or entry game to know what } \\
\text { stage I am in. }\end{array}$ & 2 & 1 & 5 \\
\hline $\begin{array}{l}\text { H3: As a user, I would like to have } \\
\text { different sections where I can evaluate } \\
\text { my knowledge according to the stage I } \\
\text { am in to perform the activities I prefer. }\end{array}$ & 3 & 2 & 13 \\
\hline $\begin{array}{l}\text { H4: As a user, I want the application } \\
\text { to show my progress depending on how } \\
\text { long I have been using the application } \\
\text { to see how much progress I have made. }\end{array}$ & 4 & 2 & 2 \\
\hline $\begin{array}{l}\text { H5: As a user, I want the application } \\
\text { to suggest activities, information and } \\
\text { recommendations based on my results } \\
\text { to improve my current state. }\end{array}$ & 5 & 2 & \\
\hline $\begin{array}{l}\text { H6: As a user, I want the application } \\
\text { to include mental reasoning games to } \\
\text { improve my cognitive memory. }\end{array}$ & 6 & 3 \\
\hline $\begin{array}{l}\text { H7: As a user, I want the application } \\
\text { to allow me to customize the games to } \\
\text { improve my user experience. }\end{array}$ & 7 & 3 & 5 \\
\hline $\begin{array}{l}\text { H8: As a user, I want the application to } \\
\text { show me the results at the end of each } \\
\text { section to observe my performance in } \\
\text { each activity. }\end{array}$ & 8 & 3 & 3 \\
\hline
\end{tabular}

\section{Result And Discussion}

\section{A. Presentation of Prototypes by user Stories}

This stage presents the design of the prototypes created based on the requirements and user stories, in order to graphically represent the functionalities of the application.

First Sprint: As shown in Fig. 3, the first sprint has a total of 14 story points, the estimated time is one month and two weeks.

H1: I as a user, I want the application to allow me to login or register to have access to all functionalities. As shown in Fig. 4, the option to log in via Facebook and Gmail has been implemented, also, in Fig. 5, in case you do not have any of the accounts you have the option to register to start using the application.

H2: I as a user, I want the application to have a test or entry game to know what stage I am in. After logging

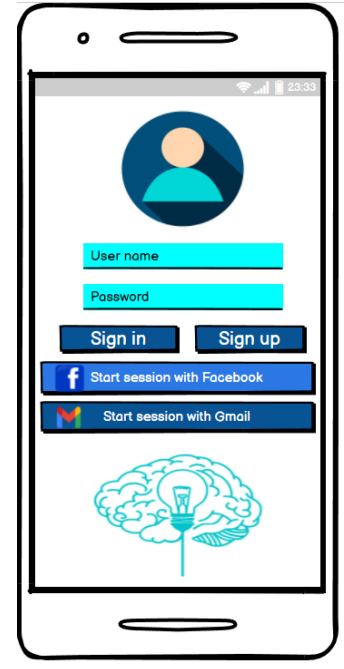

Fig. 4. Login Screen.

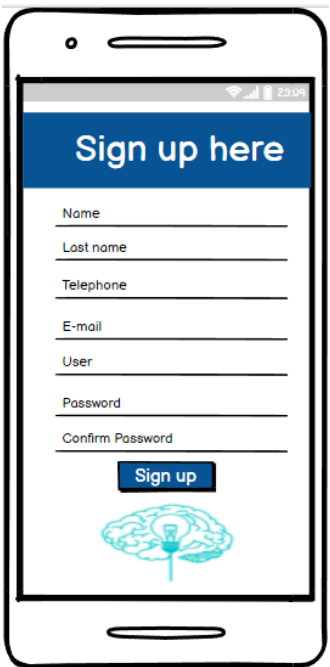

Fig. 5. Registration Screen.

in, the application automatically directs you to a 10-activity entry test to assess your current status (see Fig. 6), the app presents you with several interactive games, among them the following stand out: 4 pictures one word, crossword puzzles, mathematical problems, sound recognition (sounds of animals, things, instruments, etc.). in addition, each test has a time limit for answering. These are shown in Fig. 4 and Fig. 5.

At the end of the test, the results are shown, in the initial part it shows you where you are based on your results, Fig. 8 shows that at the end of the 10 activities, at the top shows you the result, in this case the status is "Initial", which indicates that the tests were performed in the estimated optimal time.

Second sprint:

H3: As a user, I would like to have different sections where I can evaluate my knowledge according to the phase I am in to perform the activities I prefer. As shown in Fig. 9, 6 interactive games have been developed for this story, which are intended to stimulate the mental agility of our users. 


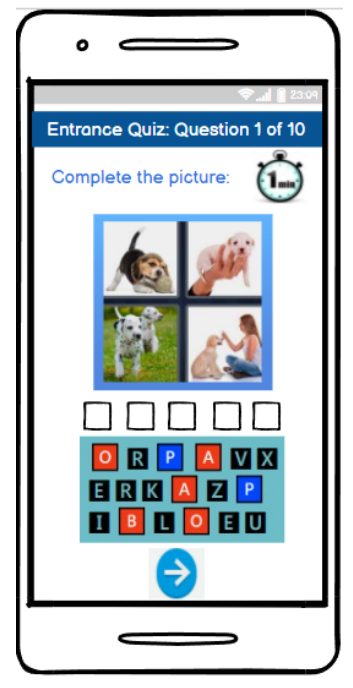

Fig. 6. Question 1 of the Test.

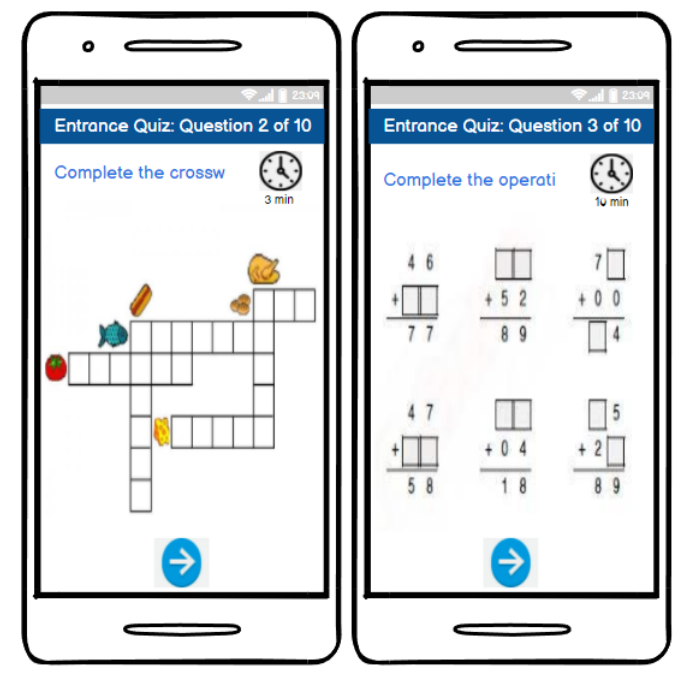

Fig. 7. Test Questions 2 and 3.

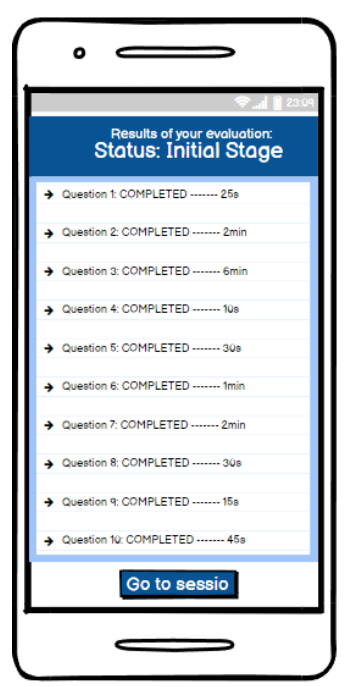

Fig. 8. Entry Test Results.

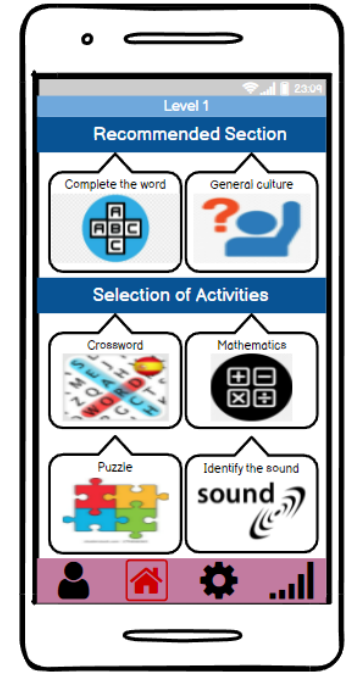

Fig. 9. Games Section.

H4: As a user, I want the application to show my progress depending on how long I have been using the application to see how much I have progressed, this functionality was implemented through general and game levels. When you select a game the app directs you to an interface where you find all the levels, this stage was designed for the user to progress over time, to pass to the next level you must necessarily finish the previous level. As you progress through the games your overall level will increase. this section is shown in Fig. 10.

H5: I, as a user, want the application to suggest activities, information and recommendations based on my results to improve my current state. As shown in Fig. 9, this can be seen in the initial part, where it is shown that "Complete the word" and "General culture" are the recommended games, this recommendation depends on your initial test result and your current condition.

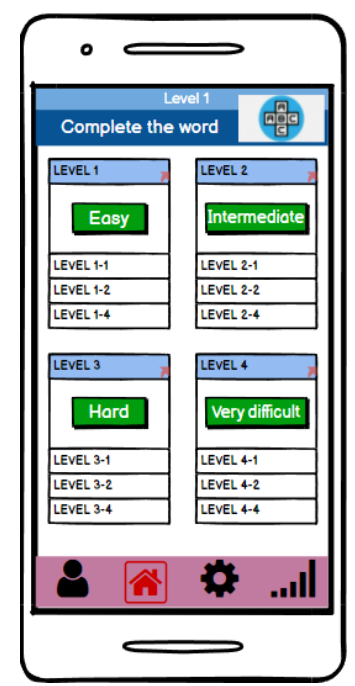

Fig. 10. Game Levels Section.

Third Sprint:

H6: I as a user, I want the application to include mental 
reasoning games to improve my cognitive memory. As shown in Fig. 7, $\mathrm{n}$ this section, mathematical reasoning problems are developed, since the team considers that it is essential to maintain an active mind.

H7: I as a user, I want the application to allow me to customize the games to improve my user experience. As shown in Fig. 11, this section allows the user to customize all games, you can change the background of each image, this function was implemented in order to make the user more familiar with the app by including images of their choice, also, has the option to include custom music for each game, since music is an active stimulant of the mind and influences the mood generally in a positive way.

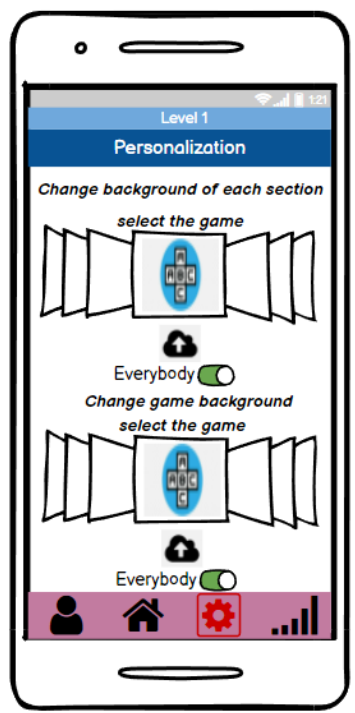

Fig. 11. Customize Games.

H8: I, as a user, want the application to show me the results at the end of each section to observe my performance in each activity. As shown in Fig. 12, this section shows the user's progress in each game, depending on the time of use, this information varies depending on the time of use. The information presented is updated daily and shows the results of the last month, order to allow users to graphically observe their progress and thus motivate them to continue making progress.

All the prototypes shown in the research were validated by testing the functionality.

\section{B. Comparison between Methodologies}

The following are a series of methodologies, which have different standards, covering all aspects of requirements, development, design and quality. Table VII shows a comparison of the requirements considered for each method studied. In this table, agile methodologies are compared, as well as with traditional methodology; This allows us to know the importance of the use of scrum in research.

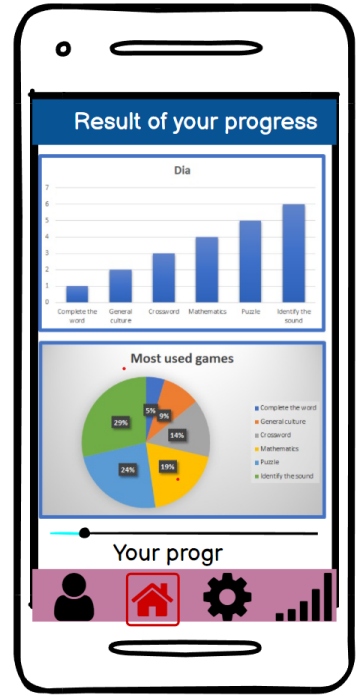

Fig. 12. Result of the use of the Games.

1) Assessment between Methodologies: Table VIII shows the evaluation of the methodologies studied and the scores obtained. The criteria are scored 1, 3, and 5, with $1=$ low, 3 $=$ medium, and $5=$ high. The criteria have allowed a score to be made according to the methodology under study, where the scrum methodology obtained the highest score. In addition, Table IX shows the 11 questions asked in the survey; this allowed for an exhaustive analysis.

\section{Analysis of the Survey Carried out for user Stories}

For the creation of the requirements, a survey of 35 people between 35 and 60 years of age was conducted, using the GoogleForms tool, the survey was conducted directly from their cell phones. The following questions were created by the development team in order to know the user's preferences. Table I shows the questions asked to the 35 respondents.

In Fig. 13, the results and user presence can be seen, thanks to this information, the functional requirements of the application were created, the following are the most relevant results for the system.

Of the 35 people surveyed, 31 prefer that the application allows you to $\log$ in through an alternative account: Gmail or Facebook, this is why it is necessary to implement this functionality in the system.

Of the 35 people surveyed, 32 agree with the creation of an initial test, which should be developed in order to determine the user's level: "Beginner", "Intermediate" or "Moderate".

\section{Analysis of Each Sprint using Burndown Chart}

At this stage, each Sprint was analyzed with the help of a graph, the $\mathrm{X}$-axis shows the time range, which has a duration of 1 month and 2 weeks (42 days). The Y-axis shows the score for Sprint 1, the analogous estimate seen in Table VI indicates that it has a total of 14 history points. The Blue line is the expected result and the Orange line is the actual result. 
TABLE VII. COMPARISON OF METHODOLOGIES

\begin{tabular}{|c|c|c|c|}
\hline & \multicolumn{3}{|c|}{ METHODOLOGIES } \\
\hline CRITERIA & SCRUM & RUP & XP \\
\hline Description & $\begin{array}{l}\text { A model that } \\
\text { is strengthened } \\
\text { by the active } \\
\text { participation } \\
\text { of all project } \\
\text { members. }\end{array}$ & $\begin{array}{l}\text { Characterized } \\
\text { by the iterative } \\
\text { and incremental } \\
\text { model. }\end{array}$ & $\begin{array}{l}\text { Extreme } \\
\text { programming } \\
\text { model, allowing } \\
\text { for the } \\
\text { incorporation } \\
\text { of new } \\
\text { functionalities. }\end{array}$ \\
\hline Type of Review & $\begin{array}{l}\text { A daily review is } \\
\text { needed, analyzing } \\
\text { the following: } \\
\text { 1. Work done the } \\
\text { day before. } \\
2 \text {. Work to be per- } \\
\text { formed. } \\
\text { 3. Tasks with im- } \\
\text { pairments or that } \\
\text { can be performed. }\end{array}$ & $\begin{array}{l}\text { In this } \\
\text { methodology, } \\
\text { the phases are } \\
\text { developed one } \\
\text { after the other, } \\
\text { thus perfecting } \\
\text { the objectives. If } \\
\text { a phase is not } \\
\text { completed, the } \\
\text { next phase is not } \\
\text { continued. }\end{array}$ & $\begin{array}{l}\text { It must be in- } \\
\text { tegrated at least } \\
\text { once a day, and } \\
\text { tests must be per- } \\
\text { formed on the en- } \\
\text { tire process. }\end{array}$ \\
\hline Objectives & $\begin{array}{l}\text { Suitable for } \\
\text { projects in } \\
\text { complex } \\
\text { environments: } \\
\text { Innovation and } \\
\text { competitiveness. } \\
\text { Get fast results. } \\
\text { Changing } \\
\text { requirements. }\end{array}$ & $\begin{array}{l}\text { Object-oriented } \\
\text { that establishes } \\
\text { the basis, } \\
\text { templates and } \\
\text { examples for } \\
\text { all aspects } \\
\text { and phases } \\
\text { of software } \\
\text { development. }\end{array}$ & $\begin{array}{l}\text { Defined by } \\
\text { giving priority to } \\
\text { work with direct } \\
\text { results. } \\
\text { Customer } \\
\text { satisfaction. } \\
\text { Group work. } \\
\text { Acting on } \\
\text { variables: Cost, } \\
\text { time, quality and } \\
\text { scope. }\end{array}$ \\
\hline Stages & $\begin{array}{l}\text { Planning. } \\
\text { Mounting. } \\
\text { Development. } \\
\text { Release. }\end{array}$ & $\begin{array}{l}\text { Home. } \\
\text { Prepared by. } \\
\text { Construction. } \\
\text { Transition. }\end{array}$ & $\begin{array}{l}\text { Define roles } \\
\text { Estimate the ef- } \\
\text { fort } \\
\text { Choosing what to } \\
\text { build } \\
\text { Program } \\
\text { Repeat. }\end{array}$ \\
\hline $\begin{array}{l}\text { Characteristics of } \\
\text { the model }\end{array}$ & $\begin{array}{l}\text { Increased } \\
\text { active customer } \\
\text { collaboration. }\end{array}$ & $\begin{array}{l}\text { Focuses on using } \\
\text { use cases with } \\
\text { an incremental } \\
\text { model. }\end{array}$ & $\begin{array}{l}\text { Emphasis on Pro- } \\
\text { gramming. }\end{array}$ \\
\hline
\end{tabular}

TABLE VIII. Evaluation by Processing CRITERIA

\begin{tabular}{|c|c|c|c|}
\hline & \multicolumn{3}{|c|}{ METHODOLOGIES } \\
\hline CRITERIA & SCRUM & RUP & XP \\
\hline KNOWLEDGE & 5 & 5 & 3 \\
\hline TIME & 5 & 1 & 5 \\
\hline ADAPTABLE & 5 & 5 & 5 \\
\hline APPLICABLE & 5 & 3 & 5 \\
\hline TOTALS & 20 & 14 & 18 \\
\hline
\end{tabular}

This leads to the conclusion that the team at the time was not consistent in its work, since the actual line is not lines, has inconsistent variations, also, the Sprint was successfully completed, this is shown in Fig. 14.

For Sprint 2, has a total of 20 story points, with a duration of 1 month (28 days). As shown in Fig. 15, the development of the project was carried out with a higher consistency, the first two weeks progress was slow and from the second week onwards the activity intensified until the Sprint was finally completed.

Finally, in Sprint 3, has a total of 16 history points, in addition, has a duration of 1 month (28 days). At this stage of the project, the team is already consolidated, since, as can be seen the expected time and the actual time does not vary much compared to the first Sprint, which indicates a greater commitment of the team to the project, the activities were developed gradually until the end. As can be seen in Fig. 16.
TABLE IX. QUESTIONS ASKED OF RESPONDENTS

\begin{tabular}{|c|c|}
\hline No & Survey Questions \\
\hline 1 & Have you played games that are based on strategy to win? \\
\hline 2 & $\begin{array}{l}\text { Would you like the application to allow you to enter through your Gmail } \\
\text { account? }\end{array}$ \\
\hline 3 & $\begin{array}{l}\text { Would you like the application to take an entrance test to know if you are } \\
\text { in the "initial", "medium" or "moderate" stage? }\end{array}$ \\
\hline 4 & Would you like the application to include basic math operations? \\
\hline 5 & $\begin{array}{l}\text { Have you solved solving puzzles and riddles? } \\
\text { health? }\end{array}$ \\
\hline 6 & $\begin{array}{l}\text { Would you like an application that allows you to play your favorite songs? } \\
\text { for the diagnosis? }\end{array}$ \\
\hline 7 & Would you like to have several games within the application? \\
\hline 8 & $\begin{array}{l}\text { Would you like to see your progress after a certain time of use of the } \\
\text { application }\end{array}$ \\
\hline 9 & $\begin{array}{l}\text { Would you like the application to show you the results of your progress } \\
\text { in a graph? }\end{array}$ \\
\hline 10 & Would you like to include levels of difficulty for each game? \\
\hline 11 & Do you think an application can improve your cognitive memory? \\
\hline
\end{tabular}

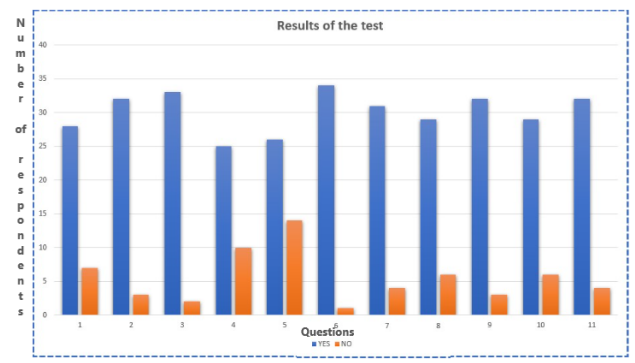

Fig. 13. Results of the Survey.

SPRINT 1

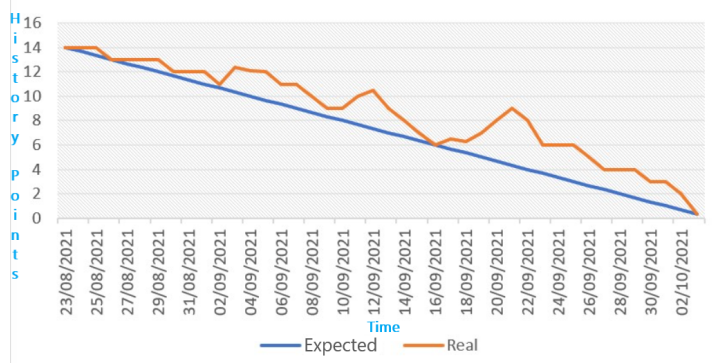

Fig. 14. Result of the First Sprint.

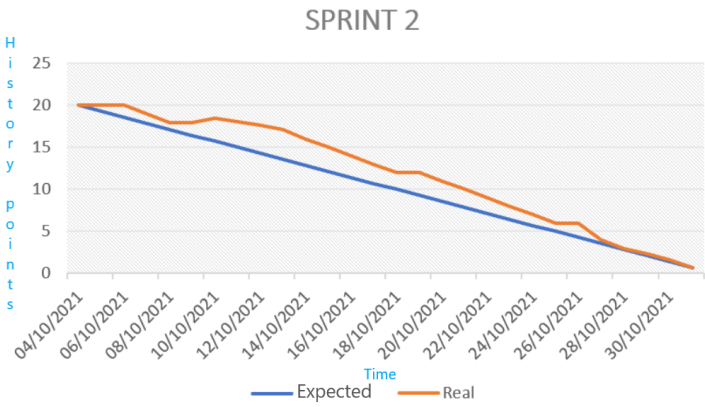

Fig. 15. Result of the Second Sprint. 


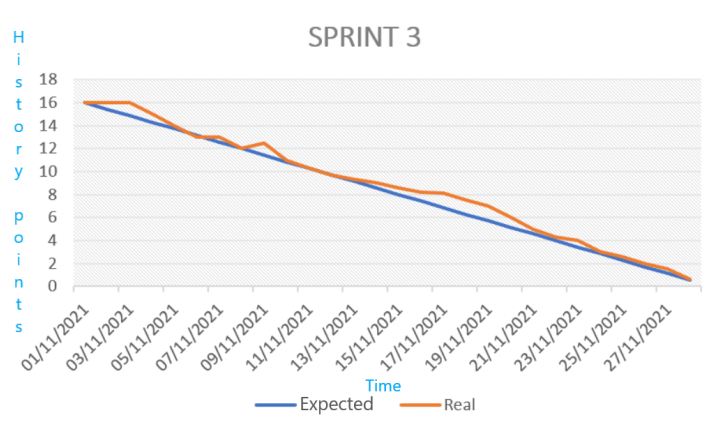

Fig. 16. Third Sprint Result.

\section{E. Analysis of Electronic Glasses to Improve Vision}

In the research, the design of glasses is presented whose objective is to improve the vision of the elderly, applying various technologies [22], including the use of augmented reality, real-time motion sensors and the use of GPS, among others, as seen in Fig. 17 and Fig. 18. The development of this research [23], will be of great help to those older adults who consume applications from their Smartphone, including our application, since it would be a pity if due to visual problems it is not possible to use our application, that is why the development of electronic glasses is a complement to take into account when thinking about the scope and comfort of the user.

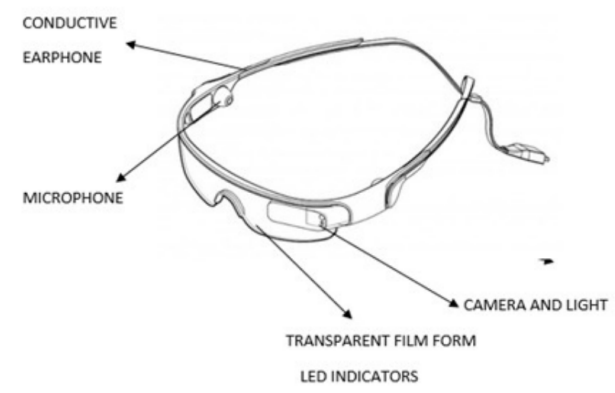

Fig. 17. Design of the Electronic Glasses [23].

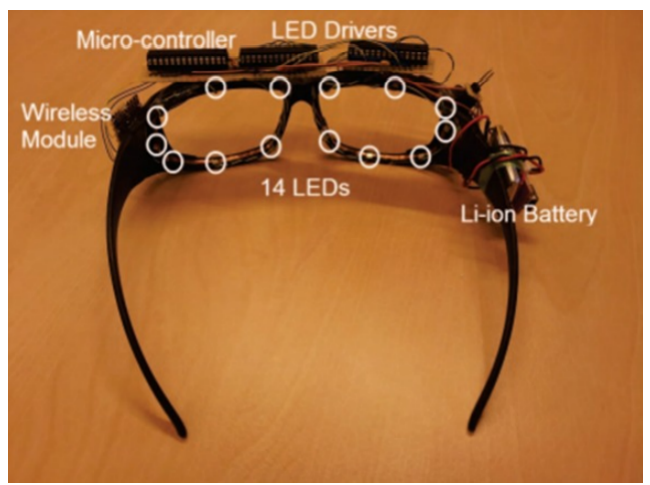

Fig. 18. LED Indicators Implanted in the Frame of the Glasses [23].

\section{CONCLUSION AND FUtURE WORK}

The research work concludes that a mobile application prototype has been developed to improve cognitive ability in older adults. The research contribution will allow the improvement of the health of these citizens. Using the Scrum methodology and applying the Balsamiq design tool, the functionalities required by the respondents were successfully represented.

In terms of methodology, the Scrum framework was of vital importance, since it allows a high-value sequential development, thus improving the quality of the application. In addition, the variety of tables and graphs provided by Scrum are the key to presenting information clearly and accurately.

In the future, it is expected that this research will be complemented with the development of a mobile application implementing the use of Artificial Intelligence to improve the initial diagnosis, also, it is suggested to apply all the steps presented above and in this way make the application a reality, as it will be very useful for people in the early stages of Alzheimer's disease, thus preventing the disease from progressing. It is expected that this mobile application will soon contribute to the health sector and be of great help to people.

\section{ACKNOWLEDGMENT}

Acknowledge the University of Sciences and Humanities, and its research institute, for their support in research. We acknowledge the support of the University of Sciences and Humanities, and its research institute, for their suggestions and recommendations.

\section{REFERENCES}

[1] R. Brito-Aguilar, "Dementia around the World and the Latin America and Mexican Scenarios," vol. 71, no. 1, 2019.

[2] M. A. Parra, S. Baez, L. Sedeño, C. G. Campo, H. Santamaría-García, I. Aprahamian, and P. H. Bertolucci, "Dementia in latin america: Paving the way toward a regional action plan," Alzheimer's and Dementia, vol. 17, pp. 295-313, 22021.

[3] L. K. Huang, S. P. Chao, and C. J. Hu, "Clinical trials of new drugs for Alzheimer disease," vol. 27, no. 1, 2020.

[4] A. E. Altinöz, F. Köşger, and A. Eşsızoğlu, "Relationship between selective attention, cognitive flexibility, response inhibition and theory of mind functions in OCD," Anadolu Psikiyatri Dergisi, vol. 20, no. 1, 2019.

[5] M. A. Pappas and A. S. Drigas, "Computerized training for neuroplasticity and cognitive improvement," International Journal of Engineering Pedagogy, vol. 9, no. 4, pp. 50-62, 2019.

[6] M. L. Gordon, L. Garys, C. Guestrin, J. P. Bigham, A. Trister, and K. Patel, "App usage predicts cognitive ability in older adults," Conference on Human Factors in Computing Systems - Proceedings, pp. 1-12, 2019.

[7] B. A. Leonardo, A. Prieto Taborda, S. Grajales Agudelo, and J. D. Pérez Rodríguez, "Aplicación móvil para mejorar la capacidad cognitiva en adultos mayores utilizando juegos mentales," Teknos revista científica, vol. 16 , no. 2 , p. 11,2016

[8] D. Griol and Z. Callejas, "Mobile Conversational Agents for Context-Aware Care Applications," Cognitive Computation 2015 8:2, vol. 8, no. 2, pp. 336-356, aug 2015. [Online]. Available: https://link.springer.com/article/10.1007/s12559-015-9352-x

[9] C. C. Quinn, S. Staub, E. Barr, and A. Gruber-Baldini, "Mobile Support for Older Adults and Their Caregivers: Dyad Usability Study." [Online]. Available: http://aging.jmir.org/2019/1/e12276/

[10] W. Mahmood, N. Usmani, M. Ali, and S. Farooqui, "Benefits to organizations after migrating to Scrum," Proceedings of the 29th International 
Business Information Management Association Conference - Education Excellence and Innovation Management through Vision 2020: From Regional Development Sustainability to Global Economic Growth, no. May, pp. 3815-3828, 2017.

[11] R. Arias-Marreros, K. Nalvarte-Dionisio, and L. Andrade-Arenas, "Design of a mobile application for the learning of people with down syndrome through interactive games," International Journal of Advanced Computer Science and Applications, vol. 11, no. 11, 2020. [Online]. Available: http://dx.doi.org/10.14569/IJACSA.2020.0111187

[12] M. Kumar and R. Dwivedi, "Applicability of Scrum Methods in Software Development Process," SSRN Electronic Journal, 2020.

[13] V. Gomero-Fanny, A. R. Bengy, and L. Andrade-Arenas, "Prototype of web system for organizations dedicated to e-commerce under the scrum methodology," International Journal of Advanced Computer Science and Applications, vol. 12, no. 1, 2021. [Online]. Available: http://dx.doi.org/10.14569/IJACSA.2021.0120152

[14] B. Singh, "Comparative Study and Analysis of Scrum and Lean Methodology," International Journal for Research in Applied Science and Engineering Technology, vol. 6, no. 3, pp. 3441-3448, 2018.

[15] M. Morandini, T. A. Coleti, E. Oliveira, and P. L. P. Corrêa, "Considerations about the efficiency and sufficiency of the utilization of the Scrum methodology: A survey for analyzing results for development teams," Computer Science Review, vol. 39, p. 100314, feb 2021.

[16] A. Tupia-Astoray and L. Andrade-Arenas, "Implementation of an e-commerce system for the automation and improvement of commercial management at a business level," International Journal of Advanced Computer Science and Applications, vol. 12, no. 1, 2021. [Online]. Available: http://dx.doi.org/10.14569/IJACSA.2021.0120177
[17] B. G. Mateus and M. Martinez, "On the adoption, usage and evolution of Kotlin features in Android development," 2020.

[18] S. Periyanayagi, A. Manikandan, M. Muthukrishnan, and M. Ramakrishnan, "BDoor App-Blood Donation Application using Android Studio," vol. 1917, no. 1, 2021.

[19] C. Khawas and P. Shah, "Application of Firebase in Android App Development-A Study," International Journal of Computer Applications, vol. 179 , no. 46, 2018.

[20] F. N. Khasanah, S. Rofiah, and D. Setiyadi, "Metode User Centered Design Dalam Merancang Tampilan Antarmuka Ecommerce Penjualan Pupuk Berbasis Website Menggunakan Aplikasi Balsamiq Mockups," JAST : Jurnal Aplikasi Sains dan Teknologi, vol. 3, no. 2, 2019.

[21] A. Carrion-Silva, C. Diaz-Nunez, and L. Andrade-Arenas, "Admission exam web application prototype for blind people at the university of sciences and humanities," International Journal of Advanced Computer Science and Applications, vol. 11, no. 12, 2020. [Online]. Available: http://dx.doi.org/10.14569/IJACSA.2020.0111246

[22] M. Gamboa-Ramos, R. Gómez-Noa, O. Iparraguirre-Villanueva, M. Cabanillas-Carbonell, and J. L. H. Salazar, "Mobile application with augmented reality to improve learning in science and technology," International Journal of Advanced Computer Science and Applications, vol. 12, no. 10, 2021. [Online]. Available: http://dx.doi.org/10.14569/IJACSA.2021.0121055

[23] L. O. Cunyarachi, A. S. Santisteban, and L. Andrade-Arenas, "Augmented Reality Electronic Glasses Prototype to Improve Vision in Older Adults," International Journal of Advanced Computer Science and Applications, vol. 11, no. 11, pp. 704-709, 2020. [Online]. Available: https://doi.org/10.14569/IJACSA.2020.0111185 